Click www.researchjournal.co.in/online/subdetail.html to purchase.

INTERNATIONAL JOURNAL OF PLANT PROTECTION

VOLUME 12 | ISSUE 1 | APRIL, 2019 | 62-66

- ISSN-0974-2670 | Visit us : www.researchjournal.co.in

\title{
Management of major insect pests of pearl millet under organic cultivation
}

G.M. Parmar*, R.P. Juneja and N.N. Chaudhary

Pearl Millet Research Station (J.A.U.), Jamnagar (Gujarat) India

\section{ARITCLE INFO}

Received : 27.01.2019

Revised : 14.03 .2019

Accepted : 19.03 .2019

\section{KEY WORDS :}

Pearl millet, Bio-pesticides, Beauveria bassiana, Organic cultivation
*Corresponding author: Email : gmparmar@jau.in

\begin{abstract}
A field experiment was conducted at Pearl millet Research Station, Junagadh Agricultural University, Jamnagar during Kharif 2016 to 2018 to find out the effective and economical control measures against the major insect pests in pearl millet for organic cultivation. The bio-efficacy of different bio-pesticides viz., HaNPV (6×109 POB/ml) @ 250 LE/ha, Bacillus thuringinensis var kurstaki @ 5\% WP @ $0.01 \%$, Beauveria bassiana 1.15 WP $\left(2 \times 10^{6} \mathrm{cfu} / \mathrm{g}\right) @ 5 \mathrm{~g} / \mathrm{lit}$, Lecanicillium lecanii $1.15 \mathrm{WP}\left(2 \times 10^{6} \mathrm{cfu} / \mathrm{g}\right) 5 \mathrm{~g} / \mathrm{lit}$ and NSKE 5 per cent were evaluated agaisnt the major insect pests in pearl millet crop. The treatment of B. bassiana $1.15 \mathrm{WP}\left(2 \times 10^{6} \mathrm{cfu} / \mathrm{g}\right) @ 5 \mathrm{~g} / \mathrm{l}$ recorded the least incidence of shoot fly $(7.2 \%)$ and stem borer $(5.36 \%)$ at earhead stage of the crop. Whereas, in case of ear head worm Helicoverpa armigera, treatment of HaNPV $\left(6 \times 10^{9} \mathrm{POB} / \mathrm{ml}\right) @ 250$ $\mathrm{LE} / \mathrm{ha}$ recorded the lowest larval population (5.78 larvae $/ 20$ ear heads) and it was at par with B. thuringiensis @ 1.0 kg/ha (8.36 larvae/20 ear heads) and B. bassiana @ 5g/l (9.87 larvae $/ 20$ ear heads). The treatment of B. bassiana@ $5 \mathrm{~g} / \mathrm{l}$ also recorded the highest grain yield (1727 kg/ha) followed by HaNPV @ $250 \mathrm{LE} / \mathrm{ha}(1490 \mathrm{~kg} / \mathrm{ha})$.
\end{abstract}

How to view point the article : Parmar, G.M., Juneja, R.P. and Chaudhary, N.N. (2019). Management of major insect pests of pearl millet under organic cultivation. Internat. J. Plant Protec., 12(1) : 62-66, DOI : 10.15740/HAS/IJPP/12.1/62-66, Copyright@ 2019: Hind AgriHorticultural Society. 